\title{
Mobilising across colour lines: Intimate encounters between Aboriginal women and African American and other allied servicemen on the World War II Australian home front
}

\author{
Karen Hughes
}

\section{Introduction}

Stationed at General Douglas MacArthur's Australian headquarters, the famous black war correspondent Vincent Tubbs reported in the Baltimore Afro-American, 25 March 1944: 'I know of 10 cases in which our boys have married Australian girls. In eight instances the girls are of mixed blood. In the other two, they are so called "pure Australian girls", adding, 'They have real concern as to how they will get their wives home on one of Uncle Sam's ships'. ${ }^{1}$

Tubbs's reportage accurately points to the significance of marriage, intimacy and the family as a key site of political struggle. Indeed, policing intimacy, coupled with immigration restriction, was central to purveying white citizenship across Australia and the United States, both settler colonial nations with distinctive, intersecting schemes of racial governance, which collided in Australia during World War II

\footnotetext{
1 Tubbs 1944: 1. The Baltimore-based Afro-American newspaper sent correspondents to cover the fighting alongside the various black American units that served in both the European and Pacific theatres. In describing the two white wives of African American partners as 'pure Australian girls', Tubbs makes explicit reference to the White Australia Policy, which had received sustained criticism in the African American press.
} 
(WWII). ${ }^{2}$ As Ann McGrath has recently noted, intermarriage was for each country 'a hidden plotline in [the desire for anchoring] settler sovereignty'. ${ }^{3}$ The narrative of White Australia in relation to both Aboriginal peoples and non-northern European migrants impacted how Australian families formed, just as, in a different context, 'Jim Crow' segregation policies and anti-miscegenation laws shaped American family formation and life, especially in US southern states. ${ }^{4}$

Over the course of WWII's Pacific theatre, more than 1 million US military personnel and support units were successively stationed across Australia from 1941 until 1947, when the last US bases were dismantled. ${ }^{5}$ This included almost 9,000 African Americans, who were mostly segregated. Alongside them, allied troops arrived from the Netherlands East Indies and Netherlands West Indies, Great Britain and colonial India, together with international merchant marines, consigned to supply the military enterprise. On the Australian home front, Aboriginal and Torres Strait Islander women and African American, Native American and other coloured servicemen were often drawn together in the face of shared experiences of colonial discrimination and oppression. From these associations, important political dialogues and activism emerged. ${ }^{6}$

With an interest in enlarging understanding of Aboriginal women's enabling roles across a number of cultural frontiers to account for broader contexts of power and social relations, I explore the multilayered impacts of relationships that Aboriginal women forged with allied servicemen on the WWII domestic front in Western Australia. Focusing on their lived experiences, working from oral history sources combined with reading the archives along and against the grain, I illuminate a larger picture of Indigenous resistance to intrusive state intervention and human rights violations, and locate these women's stories within a transnational frame of midtwentieth-century social and political change. The women's stories afford new insight into one of Australia's and the United States' most deeply hidden and neglected histories of war. While I discuss only a few women here, mostly from Western Australia, this is part of a wider national project and the subject of a forthcoming book. ${ }^{7}$ This history works alongside other important histories of the military service of Indigenous Australians, African Americans and Native Americans, to counter the unexamined acceptance of stories of white masculinist experiences on the civilian home front and in combat.

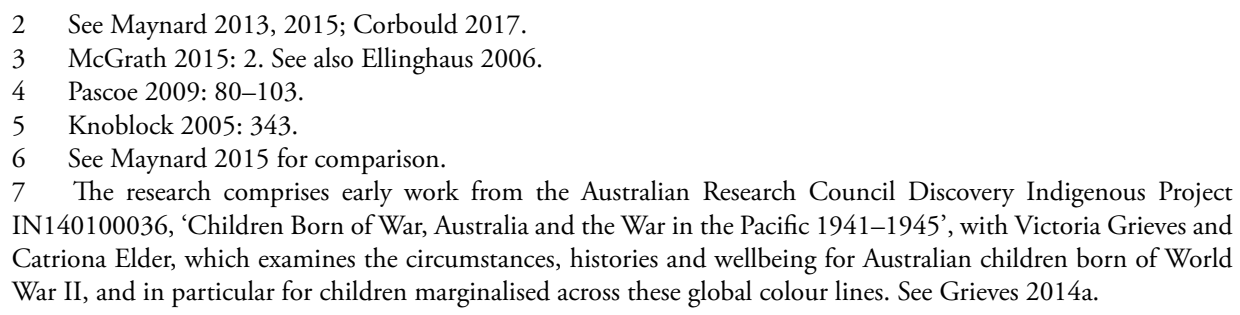


The accepted historiography is mostly silent on Aboriginal women's wartime experience and intimate relations with foreign allies. To date, Australian scholarship on transnational relations between civilians and military, and of women's emotional labour in wartime, has paid scant attention to Aboriginal women's participation. Research on Australian women's changing agency, sexuality and gender expression during WWII's 'American occupation', and its impact on mid-century postwar change, has tended to overlook the distinctive experiences of Aboriginal and Torres Strait Islander women. ${ }^{8}$ A notable exception is Stephen Kinnane's substantive, microhistorical study in Shadow Lines. ${ }^{9}$ Similarly, literature on Australian WWII war brides carries a mythic, unquestioned assumption that all of these brides were white. Some accounts refer fleetingly to the African American husbands of a number of white Australian war brides, but the trajectory of these family formations is absent from the literature. ${ }^{10}$ Research into same-sex relationships in WWII in Brisbane significantly includes the experiences of African American servicemen. ${ }^{11}$ More recently, attention has focused on Aboriginal and Torres Strait Islander women's service in the defence forces, building on an evolving body of scholarship investigating Aboriginal and Torres Strait Islander military service. ${ }^{12}$ Aboriginal women's emotional contributions on the WWII home front thus require far more nuanced exploration and centrality. Their experiences connect to a wider trans-Pacific history of intimate WWII relationships, including the resulting children born with Indigenous mothers and American military fathers, as extensively explored by Judy Bennett and Angela Wanhalla. They show that Aboriginal women's intimate relationships with African American GIs bring a fresh dimension to understanding the continuum of Aboriginal engagement with African American political consciousness of the early and mid-twentieth century. ${ }^{13}$

\section{'Defending lily-white Australia'}

During WWII, Australia's racial politics raised deep concern among America's African public. Marjorie McKenzie wrote in the Pittsburgh Courier, 'We must know if Negro troops will be sent to defend lily-white Australia, which refuses to

\footnotetext{
8 Damousi and Lake 1995: 1-20; Darian-Smith 1995: 117-29; Lake 1995: 63-66. These experiences are, however, touched on briefly by Saunders 1993: 77-78; Braithwaite 2007; McKerrow 2013.

9 Kinnane 2003.

10 Arrowsmith 2013; Strauss and Potts 1987.

11 Smaal 2015.

12 For Aboriginal and Torres Strait Islander women's military service, see Riseman 2015; Cadzow forthcoming. On Indigenous service in the defence forces more widely, see Hall 1989, 1995; Riseman 2013, 2016; Stasiuk 2008. For the Aboriginal home front in World War I, see Horton 2015; Grimshaw and Loney 2015; Furphy 2017.

13 Bennett and Wanhalla 2016; Wanhalla and Buxton 2013. On Aboriginal and African American engagement, see Maynard 2015; Curthoys and Lake 2005; Curthoys 2010. On earlier cross cultural connection between mariners, see Pybus 2006; Russell 2012.
} 
harbor any Negro population but her aborigines [sic]'. ${ }^{14}$ At the outbreak of the Pacific War, the Australian Government, gripped in the always impossible process of creating a white society, wrestled with the news of the deployment of African American battalions. The arrival of African Americans threatened to contravene the White Australia Policy and fuel populist fears of miscegenation. ${ }^{15}$ However, under the silence of wartime censorship, the first battalion of African Americans quietly slipped into Melbourne in February 1942. ${ }^{16}$ By 3 March that year, a strategic US naval submarine base was established in Fremantle, precipitated by the fall of Java. ${ }^{17}$ As their tight-knit units required a sophisticated degree of interdependency during dangerous missions, submarine crews were not radically segregated like most other branches of the US military. ${ }^{18}$ Also free from segregation, and under a blanket of secrecy, Catalina flying boat bases were located at Nedlands and Crawley in Perth, and further north at Geraldton, along with a submarine refueling station in the Exmouth Gulf. ${ }^{19}$ In Fremantle, the relocation of the Old Women's Home made way for the US Navy who were provided with the asylum and grounds for use as their Receiving Barracks for the duration of the war. ${ }^{20}$ Certain hotels in Fremantle and Perth were leased for submariners. As did the other servicemen, African Americans pooled their resources to rent houses near the Fremantle base or in the city, and were offered hospitality by local families. ${ }^{21}$

\section{'The war brought the world to Western Australia'}

'Like no other time before it, the war brought the world to Western Australia', the Miriwoong Marda Marda author Stephen Kinnane notes in his multigenerational family biography Shadow Lines. 'The Aboriginal community, usually isolated, now found themselves exposed to other peoples, if not as equals, at least in a way that had certainly not occurred before the Second World War'. ${ }^{22}$ Kinnane takes us into the world of his grandmother Auntie Jessie Smith's home in inner city Perth where 'at any one of the all-nightlong marathon card games you could find British servicemen, Dutch submariners, Aboriginal diggers and Black US sailors sitting around the table. ${ }^{23}$ War temporarily overshadowed some of the Western Australian

\footnotetext{
14 McKenzie 1942: 7, cited in Van Ryn 2011: 2. For further discussion of the African American press's reactions to 'Australia’s long record of racial intolerance', see Brawley and Dixon 2002: 614-15.

15 Elder 2007: 265; Hughes 2012; Lake and Reynolds 2008.

16 National Archives of Australia (NAA) A2684, 1330; Saunders 1987: 39-46.

17 The Fremantle base, tied in with the South East Asian theatre of WWII's Indian Ocean campaign, would become the second-largest US naval base in the Pacific theatre, following Pearl Harbor.

18 African Americans were commonly employed as stewards or officers' cooks on the submarines, although some rose to higher ranks.

19 Barker and Jackson 1996.

20 Beale 2011.

21 Knoblock 2005: 129 .

22 Kinnane 2003: 309.

23 Kinnane 2003: 309.
} 
Government's larger concerns of controlling Aboriginal peoples, and relationships formed that crossed prescribed boundaries established by the White Australia Policy and the Jim Crow laws of the US south. Many young Aboriginal women and American men encountered fresh intimate possibilities that fell outside of their usual lives, considering themselves 'kin in some way'. ${ }^{24}$ Through mobility into other spaces, WWII provided African American enlistees an opportunity to learn more about the political struggle in other countries, bolstering global solidarity that underpinned future activism and postwar political change. Strategically, African American correspondents' WWII coverage linked victory over fascism in the war to the domestic fight for equality, while ultimately connecting this to the global inequality of other colonised peoples. ${ }^{25}$ Historian Michael Green argues that by the last years of the war 'internationalist anticolonial discourse was critical in shaping black American politics and the meaning of racial identities and solidarities'. ${ }^{26}$

Aboriginal women in Perth frequently introduced their African American partners and friends to Uncle Bill Bodney, an esteemed social and political activist of African descent, who had married into a distinguished Nyungar Aboriginal family. ${ }^{27}$ Thus important political dialogues fermented. Similarly, in Melbourne, Lubin Hunter, a Native American serviceman from New York on leave, described engaging with Wurundjeri civilians: 'Being a Shinnecock, I was telling them about my part of the world, and they were telling me about their part of the world before the white man came there, and it was a very interesting experience I had'. ${ }^{28}$ Along with solid friendships, intimate relationships formed, resulting often in the birth of children. Hospital maternity wards overflowed to the extent that additional beds had to be placed in the hallways. Pregnant Aboriginal women found themselves the lowest priority, often having to leave the city to give birth in segregated hospitals outside at Moore River Native Settlement, or at Carrollup, where maternity admissions spiked. ${ }^{29}$ Some relationships were coercive; for example, Ethel Walker, a white woman down on her luck, was imprisoned for abducting underage girls from Moore River Native Settlement to be sexual partners for servicemen..$^{30}$ But, as elsewhere in Australia, a great many Aboriginal women fell in love, had casual encounters, became engaged to, or sometimes married American and other foreign servicemen. Some sadly also lost their partners in wartime action or localised violence that went unreported under wartime censorship. Marriage, as noted earlier, was not a right

\footnotetext{
24 Green 2008: 16.

25 Van Ryn 2011; Brawly and Dixon 2002.

26 Green 2008: 16.

27 Kinnane and Marsh 1993; Stephen Kinnane, pers. comm., December 2016.

28 Lubin Hunter, pers. comm., July 2016.

29 'Then there is the case of Mrs. Lionel Indich', Sunday Times (Perth), 30 January 1944: 5, trove.nla.gov.au/ newspaper/article/59191442 (accessed 1 May 2017).

30 'Back to prison', Mirror (Perth), 4 November 1944: 14.
} 
available equally to all within settler colonialism's highly policed borders, and attempts to marry across colour lines would test the immigration laws in each of these white men's countries, as we shall see. ${ }^{31}$

\section{Segregated socialising}

As Sean Brawley and Chris Dixon show in their study on the reception of WWII African American servicemen in Australia, the nature of race relations varied widely according to specific local circumstances. This observation also holds true of social relationships between African Americans and Aboriginal Australians, an aspect that Brawley and Dixon gloss over. ${ }^{32}$ In eastern Australia, the American Red Cross established separate social clubs for African American servicemen. The Booker T Washington Club in Sydney's Surry Hills, the Doctor Carver Club in Brisbane and the Red Cross American Servicemen's Club in Townsville were among those that encouraged Aboriginal women to apply for membership as card-carrying dance partners, which required a character check. ${ }^{33}$ Aboriginal women also found employment at the clubs, and two of the six Aboriginal women who joined the staff of the Doctor Carver Club married African American servicemen and later migrated to the United States under the War Brides Act 1945 (US). ${ }^{34}$

In Perth, socialising for African American troops, as with submarine battalions, was not subject to such formal segregation. The Swan Dive Club, set up by the American Red Cross in the University of Western Australia's leafy grounds, was open to all military personnel along with merchant marines. But, for most Aboriginal people, Perth remained a deeply racially segregated town - a result of 25 exhaustive years of A.O. Neville's tyrannical regime. Neville held the position of Chief Protector of Aborigines in Western Australia from 1915 to 1936, and Commissioner for Native Affairs from 1936 until his retirement in 1940. Aboriginal people were restricted to certain parts of metropolitan Perth after dark under state legislation passed in 1927, when the centre of the city itself was designated a 'prohibited zone' that soon radiated outwards. ${ }^{35}$ Consequently, engagement with these new arrivals usually occurred in private homes, or near the Catalina squadron base at Crawley and sometimes in the Aboriginal camps along the Swan River and coastal dunes flanking South Freemantle and Leighton beaches, not far from the submarine base and receiving barracks. ${ }^{36}$

\footnotetext{
31 Grieves 2014a; McKerrow 2013: 100-02; Kinnane 2003: 322.

32 Brawley and Dixon 2002: 631.

33 Moyna Richardson, pers. comm., June 2016.

34 Clarke 1994: 243-66; McKerrow 2013: 100-02.

35 Prohibited Area Proclamation, the Governor of Western Australia, 18 March, 1927, under the Aborigines Act 1905 (WA). The proclamation, along with a pass system, was in force from 1927 to 1954.

36 Kinnane and Marsh 1993; Betty Kinnane (née Smith), pers. comm., May 2017.
} 
The US Navy for its part threatened to heftily fine personnel 'fraternising' with Aboriginal women. ${ }^{37}$ Even though some Aboriginal women joined the Red Cross, volunteering as dance partners, it was made clear that they could not date the American GIs outside the club environment. Auntie Jessie Smith's daughter (and author Stephen Kinnane's mother), Auntie Betty Kinnane (nee Smith), just 16 at the time, recalled how her mother always ensured she was accompanied to these dances by an older married chaperone, and returned to Glendower Street immediately after. Betty was awarded a trophy for her dancing ability with an African American US naval partner who, as she fondly remembers, taught her the jitterbug. ${ }^{38}$ Numerous Aboriginal families, including Auntie Jessie Smith's, as noted above, set up card houses to entertain the troops and themselves ('it was our television' as the daughter of one of the attendees recalled). ${ }^{39}$ Through these marathon all-night events, Aboriginal women drew African American servicemen and others into their social, intellectual, emotional and material economies.

\section{Auntie Eileen Shang}

Auntie Eileen Shang, one of the young women who attended Auntie Jessie Smith's card nights, and hosted a great many of these herself at North Fremantle, wrote to the Commissioner of Native Affairs, midway through the war, asking permission to marry a young African American submariner from Memphis, Tennessee, the father of their soon-to-be-born son who bears his name..$^{40}$ But the commissioner had other marriage plans for Auntie Eileen Shang. Of Aboriginal and Chinese heritage from the state's north-west, Auntie Eileen had been one of the 'fair-skinned' Aboriginal children abducted to the Moore River Native Settlement, Mogumber, as a baby. Eileen had been explicitly identified by Western Australia's former Protector of Aborigines, A.O. Neville, to promote an imagined biological absorption of Aboriginal people into a presumptively white settler colonial nation. Indeed, Auntie Eileen is pictured in Neville's infamous 1940s treatise, Australia's Coloured Minority: Its Place in the Community, in which he articulates his belief that desirable assimilation of Aboriginal people of mixed descent could only occur through eugenics: 'breeding out the colour'. ${ }^{41}$ Neville attempted to orchestrate biological assimilation largely via separation of Aboriginal children from their people, training in institutions and control of Aboriginal marriage. Not surprisingly, Auntie Eileen's request to marry

37 Knoblock 2005: 320.

38 Betty Kinnane (née Smith), pers. comm., May 2017; Kinnane 2003: 315.

39 Irene Yanner, daughter of Audrey Pearson, pers. comm., May 2017.

40 James Ramsey, pers. comm., April 2016.

41 Neville 1947: plate 5, n.p. 
a foreigner of colour was bluntly refused by Neville's successor Francis Bray. With no sense of what was an absurd and crushing irony, he responded that she would likely find herself the victim of racism if she were to live in Tennessee. ${ }^{42}$

In Perth, women found to be 'fraternising' with coloured servicemen were frequently arrested by an omnipresent vice squad and often subsequently convicted under the ambiguous charge of being 'idle and disorderly'. Prison sentences were meted out of between one to four months, presumably in the hope that when the women were released their men would have been sent on war patrol or dispatched to the submarine base in Brisbane, as was commonly the case. ${ }^{43}$ Reports in the Western Australian popular press and Native Affairs Departmental files corroborate the disproportionate effort put into spying on Aboriginal women during this time, with a constant flow of correspondence between the Commissioner of Native Affairs, the Vice Squad, the American shore patrol and local police. It appears that only single women served prison terms, as it was inferred that married women would be 'dealt with' by their husbands. Thus, in the case of single women, the state stepped in to assume the paternalistic role of 'the husband'. ${ }^{44}$ Fremantle Prison must have been bursting at its seams with elevated numbers of feisty independent-spirited young women inside its thick convict-hewn walls.

The policies that led to the Stolen Generations and the massive eugenics experiment that was especially pronounced in Western Australia had marked most of these young women's lives. ${ }^{45}$ Many had been removed from their families as infants and grown up in grim institutions such as Moore River Native Settlement, later to be dispensed as cheap domestic labour for white families or confined as young adults within East Perth Girls Home. They maintained friendships with one another and devised necessary communication networks, under the watchful care of older women in the city such as Auntie Jessie Smith and her compatriots, who knew the ropes. 'It was imperative in wartime to live life to its fullest,' as Kate Darian-Smith argues, 'and to find pleasure where one could ... War injected the experiences of youth with a new urgency.' ${ }^{46}$ Frequently submariners and other military personnel had no knowledge until the last minute of when they were being sent on patrol, or when, indeed if, they were coming back. Auntie Betty Kinnane later became engaged to a white US submariner from Texas, Chuck Frieze, who attended her mother's card games,

42 James Ramsay, pers. comm., April 2016; Francis Bray, Commissioner of Native Affairs to Eileen Shang, 1944, WA Native Affairs Department files, in the possession of James Ramsay.

43 'Found asleep with Negro', Mirror (Perth), 17 March 1945: 2; 'Women talked politics to Negro', Sunday Times (Perth), 18 February 1945: 16.

44 See Pateman 2006 for an understanding of how patriarchal logic differently shaped the legal status of men and women in such cases.

45 Haebich 2000; Briskman 2003.

46 Darian-Smith 1995: 125; see also Darian-Smith 2009. 
but Frieze sadly died in combat before they could wed. ${ }^{47}$ Although censorship regulations kept reports of the air raids to the near north out of the media, the danger of further attack was known and ever present.

\section{Auntie Audrey Pearson}

Auntie Audrey Pearson, another young Aboriginal women, participated in the card games at her best friend Eileen Shang's home, drawn there by the cross-cultural camaraderie and pleasurable companionship more than the gambling. In the small wooden cottage near the wharfs, military personnel freely shared food and drink from the ships and brought wartime luxuries such as chocolate and silk stockings, along with their good manners and attention. Audrey had been born in the Salvation Army home for unmarried mothers in Fremantle in 1919. She was the daughter of 19-year-old Florence Pearson, a white woman from Menzies on the WA goldfields, and an Aboriginal man, possibly a Nyungar man from the wheatbelt, not listed on her birth certificate. ${ }^{48}$ On her engagement to a white man, Florence relinquished Audrey, aged just two, to Perth's St Joseph's Catholic Orphanage for Girls as a ward of the state. Being black, and classed an orphan, was one of the most difficult positions to occupy in Australia. Unlike for the Moore River children, there was no familial bonding for Audrey among peers: stigmatised as the only Aboriginal girl among white children, from her teenage years she worked long hours in an industrial-style laundry amid steaming hot copper boilers. Upon leaving the orphanage at 21, she came under the control of the Aborigines Act 1905 (WA). With the influx of foreign serviceman into Fremantle two years later, Audrey joined the throng of other young Aboriginal women in the city to embrace life in the moment, throwing off the isolation of her childhood and early adult years. More than once, she was sentenced to short prison terms for fraternising with American servicemen.

She told part of her story later to some of her grandchildren. ${ }^{49}$ Robert Jackson, an African American sailor stationed in Perth, had already returned to New York City when she wrote to him of her pregnancy. He replied, only to reveal that he was married and unable to support their child. Despite this disappointment, the war had given Audrey a new mobility and a different sense of identity and belonging. Having already deeply suffered the loss and subsequent death of one child forcibly taken away by the state, and of another whom she placed with a white family so he wouldn't be 'removed', Audrey went to great lengths to protect her new baby, John. After John was born in Geraldton, as the last US bases closed, she made her way up the Western Australian coast, eventually crossing the border into the Northern

47 Betty Kinnane, pers. comm., April 2007.

48 Joseph Sambono (son of Audrey Pearson), pers. comm., April 2015; birth certificate Audrey Pearson, personal archive Joseph Sambono.

49 Danusha Cubillo, pers. comm., February 2015. 
Territory, together with Eileen Shang and Eileen's young son Jimmy, to escape the oppressive regulations governing Aboriginal lives in Western Australia that regained force with the war's end.

Before reaching Darwin, they stopped in Broome for several years, benefiting from Eileen's north-west connections there. With its rich polyethnic society, built on Aboriginal-Asian relations, Broome was akin to a node in the Underground Railroad in the American south for people seeking refuge from Western Australia's south-west. ${ }^{50}$ Eileen and Audrey roomed in Old Town next to the Catholic Church with the Bin Saleh family who happily cared for Jimmy and John when they worked. ${ }^{51}$ Eileen found employment as a cook at the Broome Hospital, and Audrey at the Roebuck Hotel. Both women were forthright, smart, strong and impeccably dressed. They radiated glamour. Audrey's Broome friends recalled how she could 'talk American', something she doubtless learnt from the troops. ${ }^{52}$ Pearl Hamaguchi, who lived across the road from the Bin Salehs, delighted in spending time with John and Jimmy, observing that she had never seen women quite like their mothers before, shaped with sophistication and knowledge by their experiences of wartime Perth: 'They were hard as nails, assertive, open, honest and alive.'53

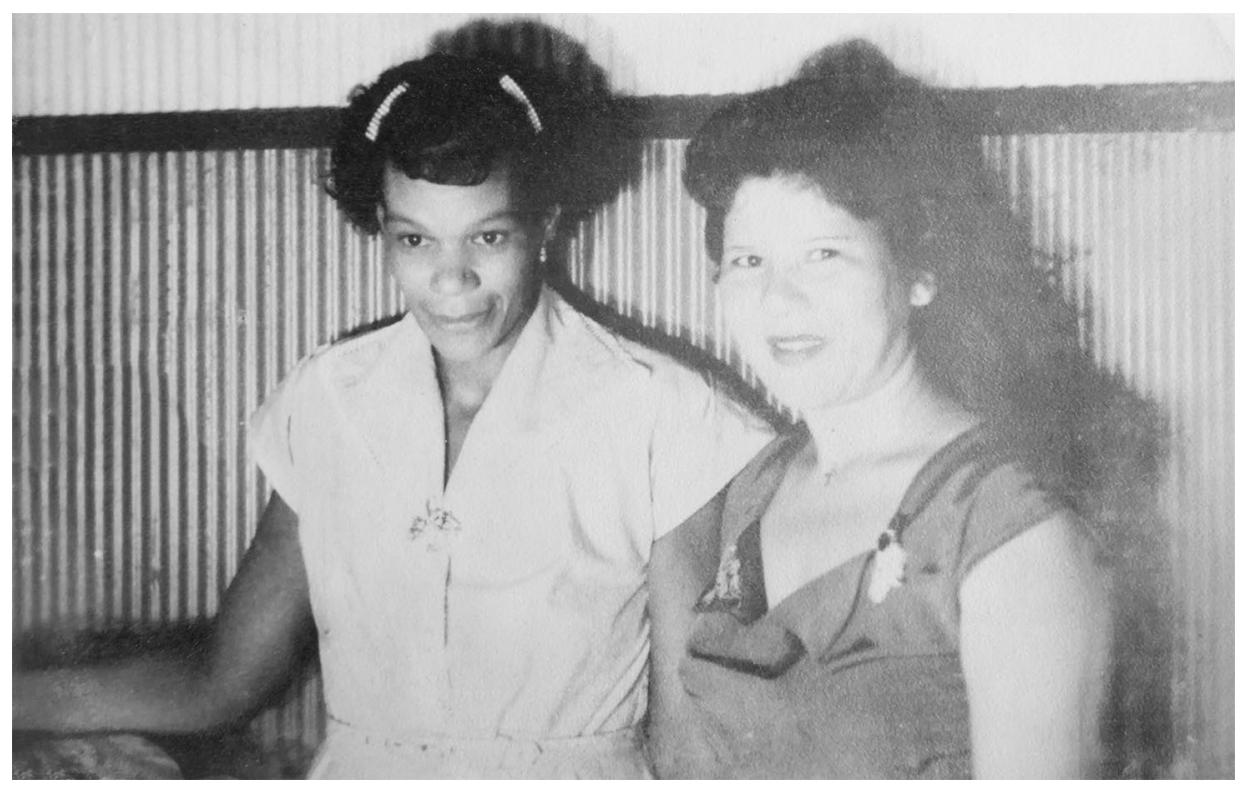

Figure 1: Audrey Pearson and Eileen Shang, Roebuck Hotel, Broome, c. 1950.

Source: Eileen Clarke collection, courtesy of James Ramsay.

50 Yu 1999; Ganter 2006; Reynolds 2003.

51 Edward Roe, Louisa Collins and Elsta Foy, pers. comm., December 2016.

52 Elsta Foy, pers. comm., December 2016.

53 Pearl Hamaguchi, pers. comm., May 2017. 
Audrey, soon followed by Eileen, made her way to Darwin in the Northern Territory, where, as Eileen would say, it was 'like paradise' after Western Australia. ${ }^{54}$ White settlement in the Northern Territory lagged behind the Australian states and, as Regina Ganter argues, was much sparser and took longer to take hold, causing less displacement. ${ }^{55}$ Moreover, many in Darwin's rich and flourishing Asian-Aboriginal population were highly politicised, and the Chinese in particular exerted economic influence. The day-to-day indignities people of colour experienced in Perth, such as being refused entry on public transport, were uncommon here. ${ }^{56}$ Audrey began to revise her identity within Darwin's public spaces, calling herself 'a Negress' as she saw this as a pass to increased freedom and rights, just as Eileen would emphasise her Chinese identity when the situation demanded. For Audrey and Eileen, the ability to shift between racialised identities that acknowledged the multilayered aspects of their lives and experiences opened up a space for the expression of personal agency and for resisting the essentialising and exclusionary racial discourse on Aborigines. ${ }^{57}$ They remained, however, ever aware of the threat Aboriginal protection legislation posed to themselves and their families, which deeply impacted their life choices.

Audrey had never known what a family looked or felt like. She had not been mothered beyond the age of two, or taught to mother within the confines of the orphanage. She was abused by nuns, for which she received compensation later in life. ${ }^{58}$ She had lost one child. Now she found her own way of extending kin, deftly keeping family within her orbit, through the network of connections she forged with families during her time in Broome, especially with the large and influential Clarke family. ${ }^{59}$ Audrey arranged for Theresa Cubillo (née Clarke), an Aboriginal woman from Broome, and her Larrakia-Filipino husband Dolphin Cubillo to formally adopt John, who was now aged four, in July 1952. The Cubillos were one of the relatively prosperous foundational families of Darwin, living in the racially mixed Asian-Aboriginal area known as the Police Paddock. Audrey, as a single mother, would otherwise have been vulnerable to having John removed by the state to an institution. This way, Audrey herself was able to live only a short block away, and maintain a connection with John as best she could. Three-and-a-half years later, in early 1956, Eileen Shang settled in Darwin permanently with Jimmy and her second child Joanne, and married Joe Clarke, living in the same neighbourhood and raising a family of six. ${ }^{60}$

\footnotetext{
54 S. Kinnane, interview with Eileen Clarke, Card Fever Research Project, Australian Institute of Aboriginal and Torres Strait Islander Studies (AIATSIS).

55 Ganter 2006: 15; Hughes 2005: 85-86; Reynolds 2003: 107-09.

56 Kinnane and Marsh 1993.

57 See Paradies 2006, for understanding of the fluid, diverse and multiple characteristics of Indigenous identities, and Sen 2006 for a nuanced exposition of multilayered identities.

58 Joseph Sambono, pers. comm., April 2016; Irene Yanner, pers. comm., May 2017.

59 Dolphin Cubillo 1984, Oral History Collection NTRS226: TS424; Joseph Sambono, pers. comm., February 2016.

60 James Ranmsay, pers. comm., May 2016.
} 


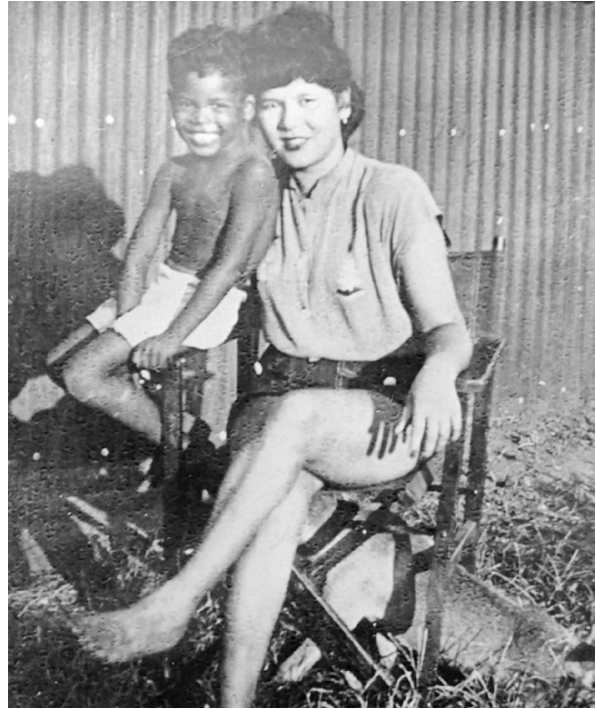

Figure 2: Eileen Shang and her son James Ramsay, Police Paddock, Darwin, c. 1951.

Source: Eileen Clarke collection, courtesy of James Ramsay.

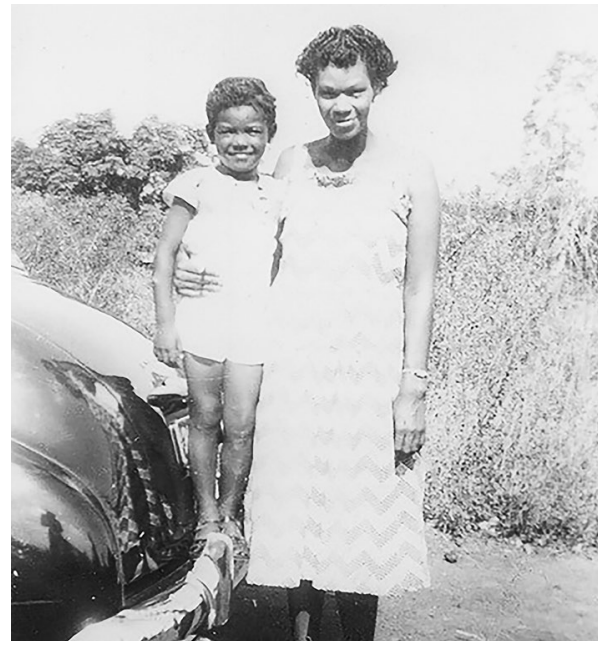

Figure 3: Audrey Pearson with James Ramsay, Police Paddock, Darwin, c. 1951.

Source: Eileen Clarke collection, courtesy of James Ramsay.

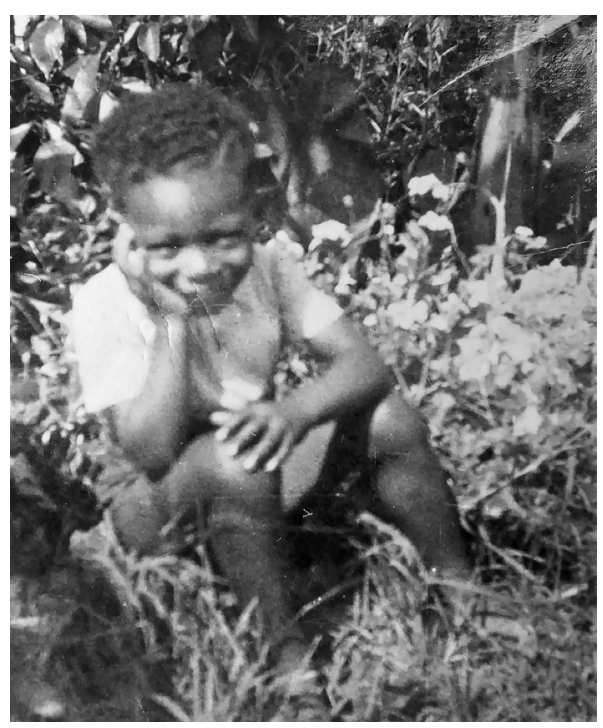

Figure 4: John Pearson (Cubillo), Police Paddock, Darwin, c. 1951.

Source: Eileen Clarke collection, courtesy of James Ramsay.

Placing children among extended kinlike circuits, whether informally or through legal adoption, as Audrey did, was an adept, resistant practice deployed by many Aboriginal women living in the Northern Territory with absent male partners to ensure their children were not forcibly adopted into white families or did not become wards of the state. ${ }^{61}$ Audrey and Eileen, each differently and together, valiantly made the best lives they could for their children at a time when there were few choices. Thus, John and Jimmy grew up in adjoining streets in Darwin's Police Paddock, now Stuart Park, and remained in contact throughout their adult lives, both working in government jobs in Darwin

61 Audrey went on to have nine more children after John; 12 children altogether. She placed them among other neighbouring friends so she could maintain maternal contact: Glen (dec.), Bob, John (dec.), Joseph, Irene, Rebekah, Peter, Serena, Bradley and Russell (twins), Alex and Rohan. 
and Canberra, respectively. They considered themselves as 'twins' because of their unique circumstances and intertwined lives that began in Western Australia during the war. ${ }^{62}$ Indeed, many of the numerous Aboriginal women who bore children with American servicemen went on to raise children, like John and Jimmy, who grew to be highly accomplished people, proud of their Aboriginal and African, Native or Euro-American heritages, who advocated for change, rights and education in productive careers.

In Darwin, Audrey, who remained single, made her living in whatever way she could at a time when employment options were limited for Aboriginal women. She cleaned houses for Darwin's prominent families and kept their secrets. In the 1970s, she put her knowledgeable life skills to good use, working as housekeeper for Judge Dick Ward who had been appointed to hear the Larrakia claims for land in Darwin. ${ }^{63}$ This arguably expanded her politicisation. Soon after, Audrey moved to Redfern, Sydney, where she became a respected elder in the Aboriginal community at a time of great political transition, living to an advanced age. In her 80s, she took up pottery and art: some of her work can still be seen in the Redfern housing estate where she lived in her later years, agitating for safer housing conditions for Redfern's elderly residents, which she brought to the attention of the national media. ${ }^{64}$ She also pressed claims against St Joseph's Homes for the physical and sexual abuse she experienced as a child, and won. Her daughter, Irene Yanner, who of all Audrey's children spent the most time with her mother, describes her as 'ahead of her time in every way'. ${ }^{65}$

\section{Marriage and the state}

The seemingly triumphant 'white-on-white' story of wartime romance and marriage shadows, as we have seen, a disturbing history of many more Aboriginal and Torres Strait Islander women and African American servicemen like Auntie Eileen Shang and her partner. In all but extremely few cases, these couples were not only denied the right to marry a partner of their choice, but also were cruelly excluded from immigrating to each other's countries, even if the hurdle of marriage could be overcome. For an American serviceman to be able marry an allied foreigner, permission needed to be first obtained from his commanding officer, and a sixmonth cooling-off period applied. Commanding officers took into account the antimiscegenation laws that operated in 29 of the then 48 American states that forbade marriages between white and non-white peoples, including African Americans, which would problematise interracial marriages if couples managed to emigrate

62 Danusha Cubillo, pers. comm., February 2015; James Ramsay, pers. comm., April 2015.

63 Ward 1975.

64 7.30 Report, 12 January 2006, Australian Broadcasting Corporation.

65 Irene Yanner, pers. comm., May 2017. 
to the United States. Australia had its own racial governance around marriage that differed across each state according to local protection laws and ordinances that required Aboriginal people wishing to marry to obtain the permission of the Protector of Aborigines or the like. Within Australia, various degrees of blood quantum applied to different locales, which, in many instances, restricted Aboriginal women from marrying white men on the one hand, or African American men on the other. ${ }^{66}$ Moreover, overarching all of these hurdles to marriage, and impacting the Aboriginal women directly, was the US federal immigration law that forbade entry to non-white people with the exception of Chinese or African descent. ${ }^{67}$ Similarly, Australia's federal Immigration Restriction Act 1901 excluded (among many others) African Americans.

One example of how these complex legal restrictions shaped the wartime experience of marriage was alluded to by war correspondent Vincent Tubbs at the beginning of this essay. This was the case of a young Indigenous woman from Innisfail, Queensland, Auntie Stella James, who worked as a clerk at the Red Cross American Servicemen's Club in Townsville, and Donald Carter Snr, an African American Sergeant from Pennsylvania. US military records indicate that it was made painfully apparent from the start, even though permission had been given to marry by Carter's commanding officer, that neither partner could live in the same country as the other because of the intersecting racial immigration restrictions in each, despite recommendations by the American Red Cross. Consequently, this meant they were also refused the right to parent their only child, Don Carter Jnr, together. ${ }^{68}$ Such exclusionary experiences bring further nuance to the history of the Stolen Generations in Australia and beyond.

Some 15,000 Australian women, fiancées and wives of American servicemen, qualified for an official war bride scheme under the War Brides Act 1945, enabling them to emigrate to the United States. However, Aboriginal and Torres Strait Islander women married or engaged to US servicemen could only gain access to this if they were able to prove to American consular authorities (or in certain cases to their Red Cross emissaries) that they had more than 50 per cent white, Chinese or African ancestry, or were exempted from 'being Aboriginal' under state regulations. ${ }^{69}$ Oral history testimonies and archival traces, including reports in the African American press and elsewhere, suggest less than 20 Aboriginal women from various parts of Australia were able to migrate to the United States, remaining there

\footnotetext{
66 Ellinghaus 2006.

67 For a more detailed explanation of the many intersecting rules and policies concerning international interracial military marriage, see Bennett and Wanhalla 2016: 18-21. However, the situation for Australian Aboriginal and Torres Strait Islander women carried the additional barrier of state-based protectorate policies intersecting with the White Australia Policy (the Immigration Restriction Act 1901).

68 See Grieves 2014a for a discussion of the marriage of Donald and Stella Carter.

69 Zeiger 2010: 87-93; Parker 2015.
} 
and raising families. ${ }^{70}$ A further four Aboriginal women from New South Wales are known to have wed members of Dutch colonial forces and migrated initially to the Netherlands East Indies. ${ }^{71}$ While it is not possible to know the exact number of Aboriginal women prohibited from marrying, such as Eileen Shang (or, like Stella Carter, once married were unable to live in the same country as their husbands), this is estimated to be in the hundreds.

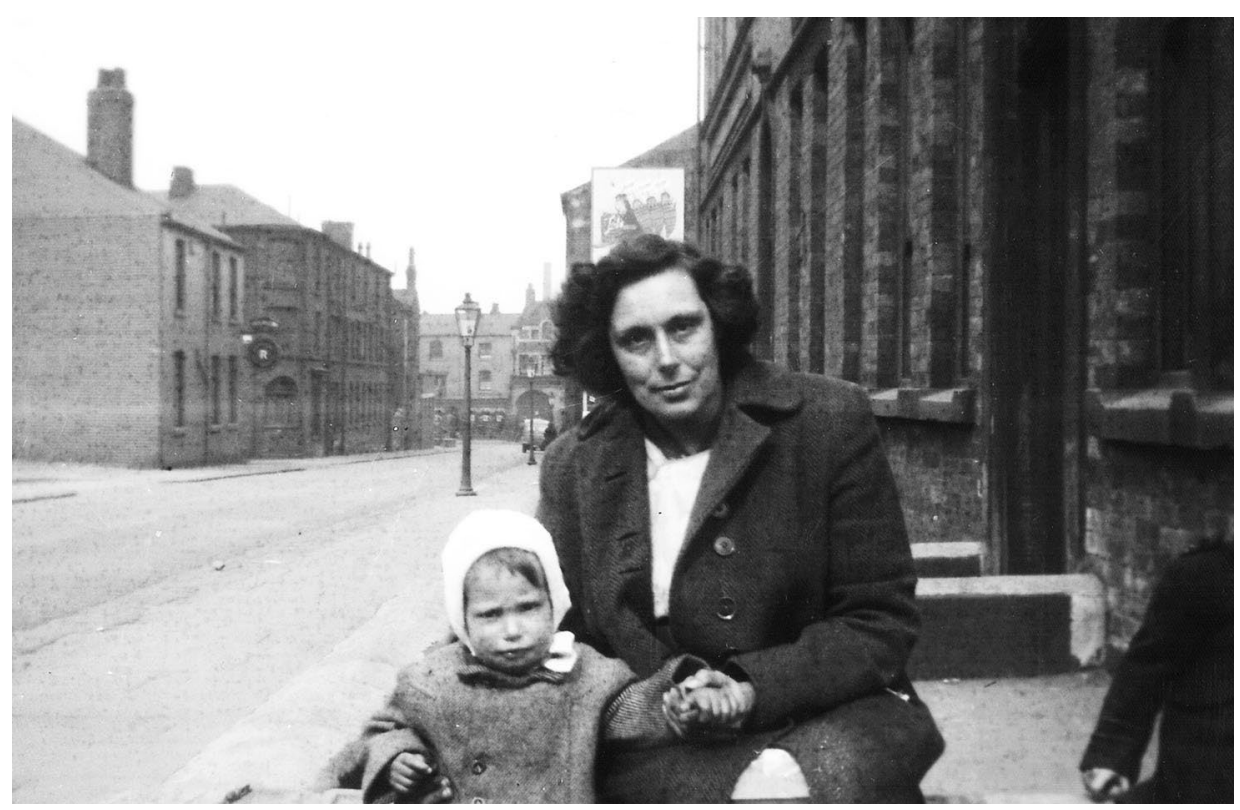

Figure 5: Patricia Beetham (née McManus) with her second-born son Peter, Leeds, UK, c. 1949.

Source: Beetham family collection, courtesy of Paul Beetham.

One Aboriginal woman from Perth, Auntie Patricia McManus, married a member of the British navy, permanently making her life in Leeds, England. When the HMS Victorius docked into Fremantle Harbour in May 1946, carrying Australian war brides from the eastern states, and set to collect more women from Perth, Pat McManus, 19 years old, single and with one son already born during the war years, was determined to try her fortune overseas and board that ship. Newsreel footage from that day records her at the docks; three weeks later, she wed crewmember Ronald Beetham and left for England, albeit against her mother Alice Brockman's wishes. Pat's son Terry remained in Perth to be raised by his grandmother. Eventually raising

70 For example, Tubbs 1944; Moyna Richardson, pers. comm., June 2016; Edith Lovegrove, pers. comm., June 2017.

71 NAA A1068 Marriages - Dutch Repatriation to Australia; 'Australian wives: Request for financial help', The West Australian, 21 April 1947: 9; 'Two Aboriginal women killed in car smash', Sydney Morning Herald, 27 January 1950: 7; 'Australian brides seek escape from Indonesia', Newcastle Morning Herald and Miner's Advocate, 21 April 1947. 
three children on her own in Yorkshire, juggling cleaning jobs after her marriage broke down, Pat chose to conceal her Aboriginal identity, instead claiming 'black Irish' descent, perhaps fearing the kind of intervention and marginalisation she had been subjected to from birth in Australia. ${ }^{72}$

\section{Back home in America}

When African American military personnel returned to civilian life, they faced exclusion in housing, discrimination in employment and the continuance of Jim Crow segregation, on top of the emotional ravages war brings. ${ }^{73}$ Many who left women and babies behind in Australia had hoped to bring them across, but were not fully cognisant of the difficulties they faced. Visiting the United States in 1947, to promote Australia's subsidy plan for US ex-servicemen to emigrate, Immigration Minister Arthur Caldwell further reduced the possibilities for these men, making it clear that African American servicemen would be ineligible, despite the protest by the National Association for the Advancement of Colored Peoples. ${ }^{74}$ Thus, yet another barrier to the possibility of family unions was imposed. Although the promise of equality on the home front was still 20 years away, studies of the Civil Rights movement routinely emphasise the significance of the participation in WWII by African Americans as crucial in catalysing change. ${ }^{75}$

\section{The Coolbaroo League}

In Perth, the wartime engagement between civilians and US military had precipitated a permanent change of consciousness for Nyungar and other Aboriginal peoples living there, as happened elsewhere in Australia. Political dialogues fomented in the card games, dance halls and along the Swan River and seaside camps impacted on the younger generation in particular. This amplified as Aboriginal veterans returned home from military service with a better understanding of their citizenship rights and a vision of what equality might look like. ${ }^{76}$ In 1946, the same year Pat McManus voyaged to England with her British husband, Helena Clarke (the cousin of Joe Clarke, who would soon become Eileen Shang's husband), Bill Bodney, Eliza Barron, the Yamitji returned soldiers Jack and Bill Poland, Ronnie Kickett and

\footnotetext{
72 Paul Beetham, pers. comm., April 2017. 'Black Irish' is a popularly used term to account for people in Ireland with dark hair or complexions, thought to be descended from the Spanish Armada. Occasionally in Australia, Aboriginal people seeking to escape widespread discrimination borrowed the moniker 'black Irish' to conceal their identity, particularly in the early to mid-twentieth century when state-sanctioned child removal was especially rampant. See Grieves 2014b: 31-32 for an example of this.

73 Kempski 2012: 2; Onkst 1998; Lewis and Lewis 2009.

74 Kalgoorlie Miner, 20 August 1947: 5.

75 Van Ryn 2011: 3.

76 Kinnane 2003: 322.
} 
others agitated for a designated space in the city for Nyungar fellowship, education, advancement and, more covertly, for change. Thus the Coolbaroo League established its base just outside the prohibited zone. In this way, the famed Coolbaroo Club dances began, explicitly taking their cue from the mixed-race wartime dances. ${ }^{77}$ The league asserted a sense of Nyungar ownership and served as a platform to lobby for an end to segregation and other pressing matters of injustice, including against widespread deaths in custody. ${ }^{78}$

This political invigoration can be seen as a direct result of the dialogues and interventions that came into being with the creation of an entirely new contact zone when the African American troops arrived on Australian soil. The influence of the African Americans was felt everywhere. Bill Bodney's home had been a critical meeting place for African American troops and their partners. Eliza Barron had a son, David, with African American navy man Malcolm Butler, and Leonard Keen, who served in the home garrison, had befriended African Americans in northern ports who provided chocolates and silk stockings to send to his sisters in Perth. ${ }^{79}$ Eileen Shang, too, later spoke of the ways some of the African American men encouraged Aboriginal people to resist the restrictions imposed on them, by tearing up the identity cards Aboriginal people were forced to display and by reporting Perth cinema owners to the American Command for refusing them admission. ${ }^{80}$ That same year, 1946, the Pilbara pastoral workers' strike in the north helped power a growing Aboriginal-led movement for social justice that cascaded throughout the second half of the twentieth century. ${ }^{81}$ Later in life, Oodgeroo Noonuccal would highlight her WWII service in the Australian Women's Army in Queensland, and the intellectual connections she formed with African American personnel, as informing the crucial role she took in catalysing political support for the 1967 Referendum. ${ }^{82}$

\section{Conclusions: Widening of possibilities}

As we have seen, policing intimacy was at the heart of reproducing white citizenship across Australian and American hemispheres. The mobility enabled by war provoked longitudinal change. Aboriginal women crossed physical and intellectual boundaries imposed by white settler colonialism, leaving permanent legacies well beyond the families they created. They also shaped the meaning of nation and citizenship through the politics of their lives. Through their agency and lived experiences, these women firmly challenged social attitudes to race, nation and settler colonial identity.

77 Kinnane and Marsh 1996.

78 Kinnane 2003: 339-42.

79 David Simmons, pers. comm., December 2016; Glen Stasiuk, pers. comm., December 2016.

80 Kinnane and Marsh 1993.

81 Hess 1994.

82 Australian War Memorial n.d. See also Riseman 2015 for an understanding of the way Oodgeroo Noonuccal's service experiences shaped her postwar cultural and political activism. 
They asserted advocacy and fostered new avenues for their children. In bearing children with African American and Native American men, Indigenous women also staunchly defied interwar policies of biological absorption aimed at 'breeding out blackness', which were particularly active in Western Australia through A.O. Neville's massive exercise of social engineering directed at assimilation of the 'halfcastes' into the white population. For many, raising their children successfully with a sensibility of their history and heritage was an overriding act of resistance in itself, forever widening the scope of the Australian family and extending Aboriginal sovereignty transnationally. Thus, 1940s Australia has been recognised by historians as critical to the development of the Indigenous and other rights movements that gained momentum in the 1960s, arising partially from the intense mobility of the war when colonised peoples actively came together like no other time before.

\section{Acknowledgements}

This work was supported by Australian Research Council Discovery Indigenous grant DPIIN140100036, 'Children Born of War, Australia and the War in the Pacific 1941-1945', and I thank and acknowledge fellow Chief Investigators Victoria Grieves (Lead Investigator) and Catriona Elder at the University of Sydney. Grateful thanks to the many family members of the women at the centre of this essay for generously sharing their histories and providing feedback and consent through different stages of the research and writing, especially James Ramsay, Paul Beetham, Cecilia Cubillo, Danusha Cubillo, Tessa Cubillo, Joseph Sambono, Irene Yanner, Donald Carter Jnr, Albert McNamara, Wayne McNamara, Stephen Kinnane, Betty Kinnane, and David Simmons. My warm appreciation to Stephen Kinnane for generously extending the project's reach in Western Australia, and to Pearl Hamaguchi and the Roe family, Broome, for invaluable insight into Aboriginal peoples' north-west experiences. My gratitude to Swinburne University for providing a research sabbatical to undertake essential fieldwork, and to the Centre for Media Culture and History, New York University, and the Fay Gale Centre, University of Adelaide, for each extending Visiting Research Fellowships, warm collegiality and intellectual stimulation. Thank you Sarah Van Ryn, Jessica Horton and Gabriel Maddock for research assistance. Various versions of this paper were presented at 'Connecting Indigenous Histories' Fulbright Senior Scholars' Symposium, hosted by the Centre for Indigenous History, ANU, and Latrobe University, 2016; the American Historical Association, Pacific Coast Branch Annual Meeting, Waikoloa, 2016; the International Australian Studies Association Conference, Curtin University, Perth, 2016; and the Berkshire Conference for Women Historians, Hofstra University, 2017. I thank colleagues at these events for their thoughtful feedback. I extend thanks to the two anonymous reviewers whose thoughtful comments have improved this paper. 


\section{References}

\section{Archival sources}

National Archives of Australia (NAA), Canberra

A1068 Marriages - Dutch Repatriation to Australia

A2684, 1330 Presence of United States coloured troops in Australia

Northern Territory Archives Service

NTRS226, Oral History Collection, TS 424 Dolphin Cubillo 1984

\section{Newspapers}

Kalgoorlie Miner

Mirror (Perth)

Newcastle Morning Herald and Miner's Advocate

Sunday Times (Perth)

Sydney Morning Herald

The West Australian

\section{Other sources}

Arrowsmith, Robyn 2013, All the Way to the USA: Australian WWII War Brides, Robyn Arrowsmith, Sydney.

Australian War Memorial n.d., 'Indigenous Defence Service', www.awm.gov.au/ articles/encyclopedia/indigenous (accessed 24 August 2017).

Barker, Anthony and Jackson, Lisa 1996, Fleeting Attraction: A Social History of American Servicemen in Western Australia During the Second World War, University of Western Australia Press, Nedlands.

Beale, Alice 2011, 'United States Navy Laundry, Finnerty Street', Report prepared for the Western Australian Museum, Perth.

Bennett, Judith and Angela Wanhalla (eds) 2016, Mothers' Darlings of the South Pacific: The Children of Indigenous Women and U.S. Servicemen, World War II, University of Hawai'i Press, Honolulu. 
Braithwaite, Sari 2007, 'Melting With Desire', Honours thesis, Department of History, The Australian National University.

Brawley, Sean and Chris Dixon 2002, 'Jim Crow Downunder? African American encounters with White Australia, 1942-1945', Pacific Historical Review 71: 607-32. doi.org/10.1525/phr.2002.71.4.607.

Briskman, Linda 2003, The Black Grapevine: Aboriginal Activism and the Stolen Generations, Federation Press, Sydney.

Cadzow, A. forthcoming, 'Servicewomen and gender relations', in Serving Country: Aboriginal and Torres Islander People and the Defence of Australia, 1899-2017, NewSouth Publishing, Sydney.

Clarke, Joan 1994, All on One Good Dancing Leg, Hale \& Iremonger, Sydney.

Corbould, Clare 2017, 'Black Internationalism's shifting alliances: African American newspapers, the White Australia policy, and Indigenous Australians, 19191948', History Compass 15(5): e12366. doi.org/10.1111/hic3.12366.

Curthoys, Ann 2010, 'Paul Robeson's visit to Australia and Aboriginal activism, 1960', in Passionate Histories, Myth Memory and Indigenous Australia, Frances Peters-Little, Ann Curthoys and John Docker (eds), ANU E Press, Canberra: 163-84.

Curthoys, Ann and Marilyn Lake 2005, 'Introduction', in Connected Worlds: History in Transnational Perspective, Ann Curthoys and Marilyn Lake (eds), ANU E Press, Canberra: 5-20.

Damousi, Joy and Marilyn Lake (eds) 1995, 'Introduction', in Gender and War: Australians at War in the Twentieth Century, University of Cambridge Press, Cambridge: 1-20.

Darian-Smith, Kate 1995, 'Remembering romance: Memory, gender and World War II', in Gender and War: Australians at War in the Twentieth Century, Joy Damousi and Marilyn Lake (eds), University of Cambridge Press, Cambridge: 117-29.

2009, On the Home Front: Melbourne in Wartime, 1939-1945, 2nd edition, Melbourne University Press, Carlton.

Ellinghaus, Katherine 2006, Taking Assimilation to Heart: Marriages of White Women and Indigenous Men in the United States and Australia, 1887-1937, University of Nebraska Press, Lincoln. doi.org/10.2307/j.ctt1djmhvp. 
Elder, Catriona 2007, “'Diggers' waifs": Desire, anxiety and immigration in post-1945 Australia', Australian Historical Studies 38(130): 261-78. doi.org/ $10.1080 / 10314610708601246$.

Furphy, Samuel 2017, 'Aboriginal Australians and the Home Front', in Australians and the First World War, Kate Ariotti and James Bennett (eds), Palgrave Macmillan, Basingstoke: 143-64. doi.org/10.1007/978-3-319-51520-5.

Ganter, Regina 2006, Mixed Relations, Asia-Aboriginal Contact in North Australia, UWA Press, Nedlands.

Green, Michael 2008. 'Black Yanks in America's Pacific: Race and the Making of a Military Empire, 1945-1953', unpublished PhD thesis, Department of History, Northwestern University, Illinois.

Grieves, Victoria 2014a, 'Children born of war: A neglected legacy of troops among civilians', The Conversation, 12 August, theconversation.com/children-born-ofwar-a-neglected-legacy-of-troops-among-civilians-29845 (accessed 1 May 2017).

2014b, 'Ngarranga Barrangang: Self and history, a contemporary Aboriginal journey', in Ngapartji Ngapartji, in Turn, in Turn: Ego-histoire, Europe and Indigenous Australia, Vanessa Castejon, Anna Cole, Oliver Haag and Karen Hughes (eds), ANU Press, Canberra: 25-39.

Grimshaw, Patricia and Hannah Loney 2015, “Doing their bit helping make Australia free": Mothers of Aboriginal diggers and the assertion of Indigenous rights', Provenance: The Journal of Public Record Office Victoria 14, www.prov.vic. gov.au/explore-collection/provenance-journal/provenance-2015/doing-theirbit-helping-make-australia-free (accessed 15 August 2017).

Haebich, Anna 2000, Broken Circles: Fragmenting Indigenous Families 1800-2000, Fremantle Arts Centre Press, Freemantle.

Hall, Robert A. 1989, The Black Diggers: Aborigines and Torres Strait Islanders in the Second World War, Allen \& Unwin, Sydney.

1995, Fighters from the Fringe: Aborigines and Torres Strait Islanders Recall the Second World War, Aboriginal Studies Press, Canberra.

Hess, M 1994, 'Black and red: The Pilbara pastoral workers' strike', Aboriginal History 18: 65-83.

Horton, Jessica 2015, "Willing to fight to a man": The First World War and Aboriginal activism in the Western District of Victoria', Aboriginal History 39: 203-22. doi.org/10.22459/AH.39.2015.10. 
Hughes, Karen 2005, 'Same bodies, different skin: Ruth Heathcock', in Uncommon Ground: White Women in Aboriginal History, Anna Cole, Victoria Haskins and Fiona Paisley (eds), Aboriginal Studies Press, Canberra: 83-107.

2012, 'Micro-histories and things that matter: Opening spaces of possibility in Ngarrindjeri Country', Australian Feminist Studies 27: 269-78. doi.org/10.10 80/08164649.2012.700260.

Kempski, Kara 2012, 'A Jim Crow Welcome Home: African American World War Veterans in Knoxville, Tennessee', MA thesis, University of Tennessee.

Kinnane, Stephen 2003, Shadow Lines, Fremantle Arts Press, Fremantle.

Kinnane, Stephen and Lauren Marsh 1993, Interview with Eileen Clarke (nee Shang), Card Fever Research Project, AIATSIS collection, Canberra, MS 3611.

1996, The Coolbaroo Club, documentary, directed by Roger Scholes, Ronin Films, Canberra.

Knoblock, Glenn 2005, Black Submariners in the United States Navy, 1940-1975, McFarland \& Company, Inc., North Carolina.

Lake, Marilyn 1995, 'Female desires: The meaning of World War II', in Gender and War: Australians at War in the Twentieth Century, Joy Damousi and Marilyn Lake (eds), University of Cambridge Press, Cambridge: 63-66.

Lake, Marilyn and Henry Reynolds 2008, Drawing the Global Colour Line: White Men's Countries and the International Challenge of Racial Equality, Cambridge University Press, Cambridge. doi.org/10.1017/CBO9780511805363.

Lewis, Catherine and Richard Lewis (eds) 2009, Jim Crow America: A Documentary History, University of Arkansas Press, Fayetteville. doi.org/10.2307/j.ctt1ffm30.

Maynard, John 2013, 'Fred Maynard and Marcus Garvey: Storming the urban space', in Exploring Urban Identities and Histories, Christine Hansen and Kathleen Butler (eds), AIATSIS Research Publications, Canberra: 153-59.

2015, 'Garvey in Oz: The international black influence on Australian Aboriginal political activism', in Anywhere But Here: Black Intellectuals in the Atlantic World and Beyond, Kendahl Radcliffe, Jennifer Scott and Anja Werner (eds), University Press of Mississippi, Jackson.

McGrath, Ann 2015, Illicit Love: Interracial Sex and Love in the United States and Australia, University of Nebraska Press, Lincoln. doi.org/10.2307/j.ctt1d98bzf.

McKenzie, Marjorie 1942, 'Pursuit of Democracy', Pittsburgh Courier, 14 March: 7. 
McKerrow, John 2013, The American Occupation of Australia, 1941-45: A Marriage of Necessity, Cambridge Scholars Publishing, Newcastle.

Neville, A.O. 1947, Australia's Coloured Minority: Its Place in the Community, Currawong Publishing Company, Sydney.

Onkst, David 1998, “"First a Negro ... incidentally a veteran”: Black World War Two veterans and the G.I. Bill of Rights in the Deep South, 1944-1948', Journal of Social History 31(3): 517-43. doi.org/10.1353/jsh/31.3.517.

Paradies, Yin 2006, 'Beyond black and white: Essentialism, hybridity and indigeneity', Journal of Sociology 42(4): 355-67. doi.org/10.1177/1440783306069993.

Parker, Kunal 2015, Making Foreigners: Immigration and Citizenship Law in America, 1600-2000, Cambridge University Press, Cambridge. doi.org/10.1017/ CBO9781139343282.

Pascoe, Peggy 2009, What Comes Naturally: Miscegenation Law and the Making of Modern America, Oxford University Press, Oxford.

Pateman, Carole 2006, 'The patriarchal welfare state', in The Welfare State Reader, 2nd edition, Christopher Pierson and Francis G. Castles (eds), Polity Press, New York: 134-52.

Pybus, Cassandra 2006, Black Founders: The Unknown Story of Australia's First Black Settlers, University of New South Wales Press, Sydney.

Reynolds, Henry 2003, North of Capricorn, Allen \& Unwin, Crows Nest.

Riseman, Noah 2013, 'Serving their country: A short history of Aboriginal and Torres Strait Islander service in the Australian Army', Australian Army Journal 10(3): 11-22.

2015, 'Escaping assimilation's grasp: Aboriginal women in the Australian women's military services', Women's History Review 24(5): 757-75. doi.org/10.1 080/09612025.2014.975499.

2016, In Defence of Country: Life Stories of Aboriginal and Torres Strait Islander Servicemen and Women, ANU Press, Canberra.

Russell, Lynette 2012, Roving Mariners: Aboriginal Whalers and Sealers in the Southern Oceans, 1790-1870, State University of New York Press, Albany, NY.

Saunders, Kay 1987, 'Conflict between the American and Australian governments over the introduction of black American servicemen into Australia during World War Two', Australian Journal of Politics and History 33(2): 39-46. 
1993, War on the Homefront: State Intervention in Queensland 1938-1948, University of Queensland Press, St Lucia.

Sen, Amartya 2006, Identity and Violence: The Illusion of Destiny, W. W. Norton $\&$ Co., New York.

Smaal, Yorick 2015, Sex, Soldiers and the South Pacific, 1939-45: Queer Identities in Australia in the Second World War, Palgrave Macmillan, Basingstoke. doi.org/ 10.1007/978-1-137-36514-9.

Stasiuk, Glen 2008, "Warriors then ... warriors still”: Aboriginal soldiers in the twentieth century', in History, Politics and Knowledge: Essays in Australian Indigenous Studies, Andrew Gunstone (ed.), Australian Scholarly Publishing, North Melbourne.

Strauss, Lucinda and Annette Potts 1987, For the Soldier of a Solider: Australian War-Brides and their GIs, ABC Press, Australia.

Tubbs, Vincent 1944, 'From Vincent Tubbs', in 'This Week', Carl Murphy, Afro-American (Baltimore), 25 March: 1.

Van Ryn, Sarah 2011, 'Carrying the torch of freedom Down Under: The African American Press campaign against Australian race prejudice during World War II', BA (Honours) thesis, University of Melbourne.

Wanhalla, Angela and Erica Buxton 2013, 'Pacific brides: US Forces and interracial marriage during the Pacific War', Journal of New Zealand Studies, NS 14: 138-47.

Ward, Richard 1975, 'Kulaluk Land Claim: Findings and Report of the Interim Aboriginal Land Commissioner', Darwin, Interim Land Commissioner, IALC, Darwin.

Yu, Sarah 1999, 'Broome Creole: Aboriginal and Asian partnerships along the Kimberley coast', in Regina Ganter (ed.) 'Asians in Australian History', Queensland Review 6(2): 49-73. doi.org/10.1017/S132181660000115X.

Zeiger, Susan 2010, Entangling Alliances: Foreign War Brides and American Soldiers in the Twentieth Century, New York University Press, New York. doi.org/ $10.18574 / \mathrm{nyu} / 9780814797174.001 .0001$. 
This text is taken from Aboriginal History, Volume 41, 2017, edited by Ingereth Macfarlane, published 2017 by ANU Press, The Australian National University, Canberra, Australia.

dx.doi.org/10.22459/AH.41.2017.03 